\title{
CLINICAL LEGAL EDUCATION: VISION AND STRATEGY FOR START-UP CLINICS IN NIGERIA
}

\section{Augustine Edobor Arimoro*, University of Cape Town, South Africa}

\begin{abstract}
:
Clinical Legal Education provides an opportunity for Law Students to, while learning, offer free legal services to the indigent community around where a law faculty is located. It is not enough to set up a law clinic without determining first of all, what role the clinic is to perform and secondly, how the clinic will aid students' learning. To have a successful clinic, it is imperative that it is well-planned with a structure to allow for funding, effective running and one that arouses student enthusiasm. The faculties of law in Nigeria have recognised that establishing law clinics will aid to achieve the vision of producing efficient lawyers who will be ready for practice soon after graduating from school. This article identifies the need to imbibe the right skills to aid student participation in law clinic activities and provides a guide to aid law faculties who wish to set up clinics or assist those already operating to realise their full potential. The article recommends the inclusion of law clinic module as one that all students must pass before graduating even though grades should not count to determine the overall Culminative Grade Point Average (CGPA) of a student.
\end{abstract}

Key words: Law Clinic, Skills, Pro bono, Law Faculty, Practice, Legal Education, Nigeria 


\section{INTRODUCTION}

The origins of Clinical Legal Education (CLE) can be traced to the advent of that mode of instruction in the twentieth century in the United States where some law schools offered community law clinics. ${ }^{1}$ In England and Wales, law clinics began to develop in the early 1970s. Clinics were set up in the Universities of Kent, Warwick and in some polytechnics that started by offering advice to students. The Kent Clinic, however, was designed to operate as a full-fledged legal practice. ${ }^{2}$ In Africa, the evolution of CLE can be traced to the emergence of law clinics in the 1970s with the first of such clinics established at the University of Cape Town in $1972 .^{3}$

The introduction of CLE in Nigeria is due largely to the efforts of the Network of University Legal Aid Institutions (NULAI). ${ }^{4}$ The first Nigerian law clinic was set up at the Adekunle Ajasin University in 2004. The University of Maiduguri and the University of Uyo followed suit in $2005 .{ }^{5}$ Other universities in the country have since gone ahead to establish law clinics in their law faculties.

Given that this article is concerned about clinical legal education (CLE) and the modus operandi for setting up pro bono law clinics in Nigerian law faculties, the need to begin

\footnotetext{
*Augustine Arimoro holds the LLB (Hons), BL and LLM degrees from the University of Maiduguri, the Nigerian Law School and the University of Derby. He recently completed his Ph.D. in Law.

${ }^{1}$ Kevin Kerrigan and Victoria Murray, (eds), A Student Guide to Clinical Legal Education and Pro Bono (Palgrave Macmillan 2011) at 7.

2 Ibid at 9.

${ }^{3}$ Olugbenga Oke-Samuel, 'Clinical Legal Education in Nigeria: Developments and Challenges' (2008)

Griffith Law Review 17 (1) at 143.

${ }^{4}$ ibid.

${ }^{5}$ ibid.
} 
with a definition for CLE is germane. Unfortunately, like other terms in the field of law, no one has offered and it will amount to an exercise in futility to attempt to offer a universal definition for the term. The definitions offered so far are largely dependent on a writer's perspective. This is similar to an African folklore about seven blind men who were asked to describe an elephant. Each one of them, described the elephant by the part that was touched depending on whether it was the trunk, tail or the foot of the animal. Grimes describes CLE in the following words:

[Clinical legal education is] a learning environment where students identify, research and apply knowledge in a setting which replicates, at least in part, the world where it is practiced.... It is almost inevitably means that the student takes on some aspect of a case and conducts this as it would be conducted in the real world. ${ }^{6}$

The problem with Grimes' definition is that it does not include the importance of legal aid and social responsibility that should characterise a legal clinic. It is imperative to note that a law clinic should combine practical legal education and legal aid. It should be more of a teaching experience with real clients. ${ }^{7}$ To the Network of University Legal Aid Institutions (NULAI), CLE is a 'multidisciplinary and multipurpose type of education which seeks to develop the skills and competences needed to strengthen

\footnotetext{
${ }^{6}$ Richard Grimes, 'The Theory and Practice of Clinical Legal Education' in J Webb and C Maugham (eds), Teaching Lawyers' Skills (Butterworths Law1996) 5.

${ }^{7}$ Mohammed M Meghdadi and Ahmed E Nasab, 'The Role of Legal Clinics in Human Tights Education: Mofid University Legal Clinic Experience' (2011) Procedia Social and Behavioural Sceince 3014-2015.
} 
the legal system, providing opportunities for learning and social justice concepts. ${ }^{\prime 8}$ This definition too does not touch on the importance of providing free services as an important aspect of CLE. In the context of the discussion running through this article, CLE is a phrase used to describe the several practical learning activities for law students. CLE maybe defined as the involvement of law students in activities geared towards the teaching of the law with opportunity to learn from real practice while at the same time providing pro bono services. This article aims to provide a guide for providing strategy for Nigerian law faculties seeking to establish a law clinic and for those with law clinics that are not currently being run to full potential. CLE serves two-fold purpose i.e. practical legal training of students and providing legal services to indigent members of the community. ${ }^{9}$ It is key in developing a strategy, that the law clinic is set up to ensure that students learn from practice. This is discussed in the next section.

\section{LEARNING FROM PRACTICE}

Participating in a Law Clinic is akin to medical students learning from experience during rounds at a ward while undertaking their clinicals at a teaching hospital. Law clinics are described as a teaching law office within a law school where students

\footnotetext{
8 Network of University Legal Aid Institutions, 'The Development of Clinical Legal Education' (2015) available at < http://www.nulai.org/index.php/blog/83-cle> accessed 21 July 2018.

${ }_{9}^{9}$ MA du Plessis, 'Clinical Legal Education: Determining the Mission and Focus of a University Law Clinic and Required Outcomes, Skills and Values' (2015) De Jure 313.
} 
participate in a supervised law practise to reflect law taught in the classroom. ${ }^{10}$ The law clinic should be conceived as a learning environment for applying the law in practice. This should go beyond mere simulations to students being presented with real cases under supervision just like medical students are presented with real patients at the teaching hospital.

It is important that students appreciate what they have been taught in theory early enough in their career to prepare them for the future. Even though, the provision of legal aid in Nigeria is primarily that of the government that set up the Legal Aid Council, ${ }^{11}$ other players such as law firms, and non-governmental organisations (NGOs) may complement the government via providing pro bono legal services. The law clinic can serve as a way of contributing to the society and be included in the corporate social responsibility (CSR) of the law faculty/university to its immediate community while at the same time providing students with the opportunity to learn from experience under supervision. Giving the high number of inmates awaiting trial due to incapacity to afford legal services, law faculties in Nigeria can be of tremendous assistance in helping to decongest the prisons. For example, according to the National Human Rights Commission (NHRC), while the Owerri prisons has a capacity for 584 inmates, as at 14 June 2016, there were 2,228 inmates in the prison with those awaiting-

\footnotetext{
10 Stephen Wizner, 'The Law School Clinic: Legal Education in the Interest of Justice' (2002) Fordham Law Review 70 at 1929.

${ }^{11}$ See the Legal Aid Act 2011.
} 
trial far out-numbering the inmates serving their prison terms. ${ }^{12}$ There is, therefore, the need to tap into the opportunity of law students and their supervisors contributing to provide a solution to this societal challenge..$^{13}$ It must be mentioned here that while students cannot practice in real courts, qualified lawyers who are attached to the clinics can do so while the students learn in the same way that medical students are taught in the various teaching hospitals in Nigeria.

A law student who participates in the faculty law clinic will benefit from interacting with professionals through the role of a lawyer serving a client. By the time that law student graduates, facing real clients in the future will not be much of a challenge as the experience gained at the Law Clinic will be handy. The argument here is that simulation can form part of what law students in the second year in the LLB programme and the third year engage in through mooting but students from LLB 4 to LLB 5 and those at the Nigerian Law School should have the experience of solving real cases. It has been argued as well that students are capable of learning far more through clinical techniques than skills developed from contextual studies. ${ }^{14}$

The benefits of law students participating in CLE are immense. The opportunity of having dealt with real cases and helping to provide solutions will prepare the student for the rigours of legal practice and make integration into the work in a law firm easier.

\footnotetext{
${ }^{12}$ National Human Rights Commission, Annual Report 2016 at 96 available at <https://www.nigeriarights.gov.ng/downloads/NHRC\%202016\%20ANNUAL\%20REPORT.pdf> accessed 18 July 2018.

${ }^{13}$ Olanike S Adelakun-Odewale, 'Role of Legal Education in Social justice in Nigeria' (2017) Asian Journal of Legal Education 5(1) at 94.

${ }^{14}$ Kevin Kerrigan and Victoria Murray, op cit (note 1 ) at 7.
} 
For example, interviewing skills, drafting of documents and motions can be learnt before the student lawyer graduates from the law faculty. The argument in this article is that involvement in real cases will impact more on the students than mere simulation. Live client clinic offers the best opportunity to learn from spontaneity, authentic emotion and personal obligation. $\cdot{ }^{15} \mathrm{~A}$ law clinic that is merely framed to have just simulated cases may not fully realise the potential of CLE. The aspect of providing pro bono services to the community as a way of social responsibility will also be lacking. It is therefore, of importance, that this is taken into consideration in the planning and setting up of law clinics in Nigerian law faculties. A good example is the Women's Law Clinic of the University of Ibadan. The clinic provides services to live clients principally on women-related issues such as counselling on women's and girls' rights. ${ }^{16} \mathrm{CLE}$ should be more than just organising gatherings for public education on the rights of citizens as practised by some law clinics in Nigeria. The approach of using guest lecturers to teach students in a law clinic setting appears to be more like the traditional method of the theoretical teaching of the law. A clinic ought to be a clinic. It should be the lawyer's equivalent of a medical clinic and nothing less. Having discussed the law clinic as an opportunity for the student to learn from the practice of law, the next section of this paper discusses the skills that a law student should possess or acquire to effectively participate in the law clinic while learning at the same time.

\footnotetext{
15 ibid at 9.

16 Olanike S Adelakun-Odewale, op cit (note 12) at 91.
} 


\section{SKILLS FOR LAW CLINICS}

It is imperative that participating law students develop the skills required to be efficient working at the law clinic. First, for a student to be resourceful at the law clinic, the student needs to have a broad knowledge of the legal system including legal concepts, values, principles and rules. It is important that while introductory law courses are being taught at the early stages of the undergraduate career, the modules are prepared with this in mind. As such, it is recommended that the modules be revised to allow for simulation and the content be in touch with real application situations. Based on the foregoing, CLE is suitable for students in the fourth and fifth years of the LLB honours programme in Nigeria. Secondly, students should be able to demonstrate the ability to apply knowledge and provide the required arguable conclusions for actual or hypothetical law problems. Thirdly, students must be taught to imbibe research skills. This skill set is key to finding solutions for legal problems or issues. The students should demonstrate the skill to identify the problems in any given case, find out what area of law is in issue, research it and retrieve up-to-date information relevant to the case using a variety of primary and secondary sources of research. Fourthly, students require good interviewing skill. It is important that the relevant information is sourced from the client. A good mastering of this skill is a vital ingredient for law practice. It is key that the students are trained on how to conduct client interviews. All interviews must be prepared for. There must be an interview plan and a method for sourcing information. It is imperative, that all participating students go through a training before being admitted to participate in the clinic. Fifthly, Participating students should demonstrate good oral and communications skills. Working at a law clinic requires extensive communication. One way to develop this skill set is practice. Sixthly, A law student should possess the ability to recognise and prioritise issues; bring together materials from diverse sources; make critical judgements; and present the appropriate choice from a selection of solutions. The clinic should be organised to emphasise 
this key area of training as it will be beneficial to the student in the future practice of law. Other skills required include the ability to use, present and assess numerical data, create wordprocessed documents, use ICT resources such as email and the ability to browse the internet. It is equally important that all participants must imbibe team work. Working as a team at the law clinic will be useful to the law students preparing for a career in legal practice. This should be imbibed in the students through their engagement in group tasks. In this wise, it will be effective to organise the students into various groups of say, four students each. Each group should be assigned its own case with the members of the group performing different tasks to achieve the group objective. For example, in a group of four handling a case, one person may conduct the interview with the client, a second person researches the law, a third person writes the brief and the fourth person is responsible for writing all communications with the clients. Even though, each group member may be assigned a specific task, they are all to discuss and review the tasks performed by each member of the group.

In Australia, the Queensland University of Technology, following the path of Australian Law Reform Commission's 2000 exhortation to re-orientate legal education around ‘what lawyers need to be able to do,' have grouped the skill sets law students need into four different categories namely, attitudinal skills, cognitive skills, communication skills and relational skills. ${ }^{17}$ See table below for the skill sets listed under each of the four categories mentioned above.

\footnotetext{
${ }_{17}$ Sally Kift, 'A Tale of Two Sectors: Dynamic Curriculum Change for a Dynamically Changing Profession' (2003) Being a Paper Presented at the Developing the Law Curriculum to Meet the Needs of the $21^{\text {st }}$ Century Legal Practitioner Conference (Melbourne, Australia) 13-17 April 2003 available at < https://core.ac.uk/download/pdf/10877994.pdf> accessed 24 September 2018.
} 
Table 1: Skills by Category

\begin{tabular}{|c|c|c|c|}
\hline Attitudinal skills & Cognitive skills & $\begin{array}{c}\text { Communication } \\
\text { skills }\end{array}$ & Rational skills \\
\hline Ethical orientation & Problem solving & Oral communication & Work independently \\
\hline Creative outlook & Legal analysis & Oral presentation & Teamwork \\
\hline Reflective practice & IT literacy & Advocacy & $\begin{array}{l}\text { Appreciate race, } \\
\text { gender, culture and } \\
\text { socio-economic } \\
\text { differences and } \\
\text { diversity generally }\end{array}$ \\
\hline $\begin{array}{l}\text { Inclusive } \\
\text { perspective }\end{array}$ & Legal research & Legal interviewing & Time management \\
\hline $\begin{array}{l}\text { Social justice } \\
\text { orientation }\end{array}$ & $\begin{array}{l}\text { Document } \\
\text { management }\end{array}$ & Mooting & \\
\hline Adaptive behaviour & $\begin{array}{l}\text { Discipline and } \\
\text { ethical knowledge }\end{array}$ & Negotiation & \\
\hline \multirow[t]{2}{*}{ Pro-active behaviour } & & $\begin{array}{l}\text { Written } \\
\text { communication }\end{array}$ & \\
\hline & & Drafting & \\
\hline
\end{tabular}

Other skills that will be useful for a law clinic include counselling, factual investigation, the development of personal strategies to enhance performance and ethics. ${ }^{18}$ To get the best of the law clinic in terms of work quality and to enhance students' learning, the law school needs to consider this skill set as a factor that should guide student recruitment and the foundation modules in the curriculum for law

${ }^{18}$ MA du Plessis, op cit (note 9) 324-325. 
training. Where this is done effectively, by the time the students graduate from the vocational law schools, ${ }^{19}$ they would be ready to be integrated into law firms in the country with little orientation needed.

Having identified the skills that law students require to efficiently participate in the law clinic, it remains to be stated that there are values that the law faculty should promote alongside these skills. This is important in the quest to train efficient, passionate and dedicated lawyers for the future. For example, the goal of the law faculty of the University of Maiduguri is stated as follows:

\section{Vision}

To be a world-class law faculty which produces highly disciplined law graduates that will provide quality legal representation to the people as well as cater for the contemporary legal needs of the society. ${ }^{20}$

\section{Mission}

The mission of the faculty is:

- to inculcate in our students the values of decency, hard work, loyalty and self-discipline

- to produce high quality law graduates within a serene and peaceful academic environment who will complete favourably globally and

- to provide transferrable skills through ICT driven legal training and clinical legal education (CLE) to students to enable them perform tasks and execute responsibilities with the highest degree of professionalism. ${ }^{21}$

\footnotetext{
${ }^{19}$ In Nigeria, after a compulsory 5-year LLB honours programme at the various law faculties, students who wish to be admitted as solicitors and advocates of the Supreme Court of Nigeria must attend the Nigerian Law School for a one year or two year (for students who studied law abroad) programme.

${ }^{20}$ Faculty of Law University of Maiduguri, 'Welcome to the Faculty of Law' available at < http://www.unimaid.edu.ng/faculty/law.html> accessed 24 September 2018.

${ }^{21}$ Ibid.
} 


\section{Objectives}

Main objective of the law programme is to train students who upon graduation will proceed to the Nigerian Law School where they will undergo the one-year compulsory training for the purpose of being called to the Nigerian Bar.

Specific objective of the law programme is to produce lawyers that will fit in well in all sectors of the society, be it in the judiciary, private legal practice, public sector, private sector or even the armed forces. This objective is of particular importance to the states that make up the University's catchment areas that depend on the Faculty to provide both high and low levels manpower to serve on both the Bench and the Bar. ${ }^{22}$

In line with these values promoted by the faculty of law, University of Maiduguri, it has been noted that every lawyer must embrace the following: 'competent representation; striving to promote justice, fairness and morality; striving to improve the profession; professional and self-development; judgement; professionalism; civility and conservation of the resources of the justice system.' ${ }^{23}$ The skills set for law students to perform effectively in a law clinic have been enumerated and discussed above. In the next section of this article, the setting up of a law clinic is the focus.

\section{Case Study of the University of Maiduguri Law Clinic ${ }^{24}$}

The Maiduguri Law Clinic (MLC) was set up in February 2005 following the approval of the University Senate for the commencement of Clinical Legal Education in the University. Consequently, the MLC was registered as a member of the Network of

\section{Ibid.}

${ }^{23}$ MA du Plessis, op cit (note 9) 326-327.

${ }^{24}$ The information under this section is sourced from the Network of University Legal Aid Institutions Compendium of Campus Based Law Clinics in Nigeria 2014. Additional information was supplied by Dr Abdul Rasheed, one of the Law Clinic Supervisors. 
Universities Legal Aid Institutions (NULAI). The MLC started operations on $9^{\text {th }}$ December 2005. The clinic also, under a memorandum of understanding (MoU) with German Agency for Technical Cooperation (GTZ) serves as a model for the provision of mediation and legal services for women and children.

CLE is offered at the University as an elective course for students in LLB IV (fourth year) as well as for those in LLB V (fifth year) of the five year law degree programme. The MLC adopted the NULAI model of the CLE curriculum. The objectives of the MLC are first, the training of law students to become highly qualified public interest attorneys by serving the needs of the community and those of individual members of the community through legal representation, advice and education. Secondly, the opportunity to provide opportunity to law students to have first-hand experience in the practical application of law and thirdly, to develop skills of client counselling, negotiation, advocacy ad litigation within a supportive learning environment.

The recruitment process for the MLC is as follows: applicants must be in the fourth or fifth year of the five year law degree honour programme. To be eligible for selection, a candidate must meet a minimum CGPA grade point. The second stage consists of a written and oral interview. Other criteria for eligibility include gender and the geopolitical state of origin of a candidate. At the University, CLE is taught as a course for both the fourth and fifth years. In the first semester of the fourth year, students study Clinical Legal Education (LW 414) which is a 3 unit course. They are taught interviewing and counselling skills, legal writing 1, Legal research and they undertake field work exercises. In the second semester of the fourth year, students take the 
Clinical Legal Education (LW 415). They are taught ethics, information and communication technology, legal writing 2 and they also undertake field work. In the fifth year, students enrolled for CLE take Practical Lawyering Skills (LW 512) where they learn Alternative Dispute Resolution (ADR), introduction to practice management and undertake clinic work. In the second semester of the fifth year, students learn Practical Lawyering Skills (LW 513). The course outline includes public interest lawyering, access to justice and they undertake work in the clinic. Students who take CLE are evaluated based on 30 percent of continuous assessment and 70 percent for examinations for both year four and year five students.

The MLC serves as an in-house clinic with a street law component and a prison service unit. The clinic is run by students in the fifth year of the five year course. The students are divided into four groups and allocated clinic days in accordance with a schedule for clinic management and client consultation. The clinic is open Mondays through Fridays from 09.00 to 16.00 hours. The main areas of focus for the clinic include human rights, ADR, matrimonial/reproductive health and rights, labour related matters, child rights and prison and pre-trial detainees. The services provided include counselling/legal advice, mediation, child rights support, legal support services, citizenship/community sensitisation and case referrals.

\section{SETTING UP A LAW CLINIC}

In this section, the focus is on the strategy to be employed in setting up a clinic for a law faculty within the Nigerian context. There are key issues that need to be addressed 
for the establishment of a successful law clinic or for the development of already existing clinics. The aim is to ensure that the full potential of CLE is achieved and that the students get the real experience of working in a law firm even while they are still students. The guidance provided in this article is for clinics that are designed as pro bono live-clients law clinics. The steps required to establish a sustainable CLE project in a Nigerian law faculty are considered below.

Having decided that a clinic is to be established, the next call is to decide on where the clinic is to be positioned. ${ }^{25}$ In the case of Nigeria, the clinic is suitable for the LLB programme and not for those pursuing post-graduate studies. The steps required in the setting up of the law clinic are discussed in sub-sections below.

\section{Getting Support}

Since the law clinic is to be set up in the University, it is important that some factors are taken into consideration. The support of the University Vice Chancellor and/or governing council is required. This is because, the University may need to bear the start-up costs for the project. There will be the need for an office within the law faculty or the university premises accessible to client. Approval for this can only come from the university authorities. It is noted that 'wheels tend to turn slowly in academia,'26 as such, there is a need for a great deal of patience and follow-up to ensure that approval is obtained. The law faculty may also approach alumni, NGOs,

\footnotetext{
${ }^{25}$ Ronan Fahy and Mirreille van Eechoud, Establishing a Start-up Law Clinic in Law School: A Practical Guide (ICT Law Incubators Network 2015) at 5.

${ }^{26}$ Kevin Kerrigan and Victoria Murray, op cit (note 1) at 22.
} 
philanthropists and funding bodies for support as there will be costs associated with setting up of the office. There will be need for office equipment including furniture, desktop computers/laptops, internet, telephone, stationery and for the services of a full-time clinic staff or clerk.

Ordinarily the dean of law of the faculty should be in support of the establishment of a law clinic in the faculty. It is the responsibility of the dean to appoint a champion who would serve as the vision driver. It is better if a member of faculty is employed principally as the legal director of the clinic as you would have a medical director in a teaching hospital. It is also in order if a member of faculty combines the responsibility of managing the clinic with some teaching in the faculty as well. The important thing is to have a member of staff who will be in charge and be accountable for the successful running of the project. Other staff members too may be delegated to the clinic to perform specific roles.

\section{Recruiting Student Counsel/Advisors/ Participants}

Having decided on the need to establish a law clinic, it is vital to consider how participating student counsel are to be recruited. It is recommended that CLE be made compulsory for all LLB four students and be optional for LLB five students. For students in the lower classes, moot court activities can be encouraged while they learn the theoretical aspects of the law in preparation for the CLE programme in their fourth and final years in the LLB programme. It should be optional for students in the final year, who at that level would have decided whether they wish to practice as 
lawyers in chambers in the future. In this case, all students in the fourth year are to be selected in groups to take turns at attending to clients at the clinic.

To get the best out of the students, it is important that CLE be graded for participating student counsel. From experience, where the clinic is merely structured as an extra-curricular activity, students are usually not committed. Academic credits should therefore be given to participating students. It is recommended that a pass or fail grade model be used instead of specific grades and the result should not count towards the Grade Point Average of a student, but a pass must be required to graduate from the LLB programme.

\section{Identify the Target Audience for the Clinic}

It is important to determine what audience the clinic is to serve. This will determine the design and structure of the clinic. While it is given that as a part of the university's social responsibility project, the primary clients of the clinic would be the immediate community where the law faculty is located, the type of cases the clinic can handle must be determined from the start. Furthermore, whereas it is important that the clinic aspire to reach as many potential clients as possible, ${ }^{27}$ since the more the clientele, the better the learning opportunity. Nevertheless, a student clinic cannot handle all types of cases. The clinic may only take on cases where there are sufficient resources to handle such cases. Where a clinic does not have the capacity to handle a case, this should be made known to the client as quickly as possible in order not to raise false

\footnotetext{
${ }^{27}$ Guy Alvarez, 'Law Firm Target Audience: Reaching Your Ideal Client' (2018) available at < https://good2bsocial.com/law-firm-target-audience/> accessed 23 July 2018.
} 
hopes. Civil matters such as landlord and tenant cases, contractual matters, civil wrongs, employment disputes and criminal cases pertaining to those awaiting trial should form the core area of practice at the law clinic. Specialist matters like matrimonial causes, intellectual property rights etc should not be entertained.

\section{Identify and Engage the Key Stakeholders}

There are various key stakeholders that determine how successful a project would become. In the business plan for the clinic, it is important that roles are specified to ensure that all stakeholders identify and play their part. Clarity of roles will help drive the project on the path to success. The core clinic team must be identified from the start. These are:

\section{i. The Legal Director}

The legal director is to the law clinic what a medical director is to a teaching hospital. The person occupying this position, who ideally, should be a member of the faculty, must be the champion of the clinic and have the support of the dean and the university authorities. The legal director should oversee the budget for the clinic and provide policy directions as well as determine the areas of practice.

\section{ii. The Supervising Lawyer}

It is recommended that a legal practitioner with experience be employed and attached to the clinic. The lawyer may be assigned teaching responsibilities as well with a primary responsibility to appear in court where required. The Supervising lawyer may also be the legal director if there are staffing issues. It is important to appoint 
someone with a wide experience of different areas of practice to this position especially in areas that the clinic will like to focus on. ${ }^{28}$

iii. Supervisors

Supervisors should be drawn from members of the faculty to oversee the different groups. Their task should be to review the work done by the student counsel. They may or may not be practising lawyers. Their job is to oversee work done and have the student counsel pass it on to the supervising lawyer who should review it and approve letters of advice to clients and where necessary represent such clients in court. iv. Academic Consultants

Some faculty members can be retained as consultants. Those members of the faculty who teach modules such as torts, contract, property law, criminal law, civil and criminal procedure as well as the law of evidence, should help the students as the need arises.

\section{v. Student Advisors/Counsel}

These are the students who participate in the clinic and relate with clients. They are expected to have the most contact with the clients and manage the cases under the supervision of the supervisors and/or the supervising lawyer.

\section{The Facility for the Law Clinic}

Careful thought needs to be given to the facility to be used for the clinic. The office space for the clinic should be exclusive to the clinic and accessible to clients. If the law

\footnotetext{
${ }^{28}$ Kevin Kerrigan and Victoria Murray, op cit (note 1) 31.
} 
faculty is not accessible to members of the public, it may be wise to locate the law clinic in an area in the university that is more accessible. The working space should be big enough to accommodate key clinic staff and conducive enough to have visitors. There should be a reception area for clients and guests who are waiting to be seen. Care must be taken to separate this from the work area to protect the confidentiality of clients and to ensure clients do not see or get access to confidential information. The interview room should be conducive for at least four persons, with two student interviewers, a supervisor and the client attending. There is the need for storage and filing cabinets.

Office equipment such as computers and internet should be provided. For research, students may use the university law library. The clinic should have a dedicated line with which clients can reach the office. The office will require a photocopier, a shredder, a document scanner, digital camera, audio playback equipment, stationery and all the essentials required for running a law office.

The office will need furniture such as desks, chairs, filing cabinets and book shelves. ${ }^{29}$ The following checklist of supplies should serve as a guide for supplies and equipment essential for a law clinic:

\footnotetext{
${ }^{29}$ Find Law, 'How to Start a Law Firm: Office Furniture and Supplies' (2018) available at < https://practice.findlaw.com/how-to-start-a-law-firm/how-to-start-a-law-firm-office-furniture-andsupplies.html> accessed 24 July 2018.
} 
Table 2: Office Equipment for Law Clinic

\begin{tabular}{|cl|l|}
\hline Item & & Check \\
\hline i. & Envelopes & \\
iii. & Stationery & Paper (a 4-size) \\
iv. & Supply of sticky notes & \\
v. & Pencils & \\
vi. & Pens & \\
vii. & Staplers & \\
viii. & File folders & \\
ix. & Three ring binders & \\
$x$. & Staple removers & \\
$x i$. & Scissors & \\
\hline
\end{tabular}

The above list is certainly not all-inclusive but constitute the essential items that are required for the law clinic.

\section{PRACTICE STRATEGY FOR THE CLINIC}

In medical practice, bedside teaching affords clinical students the opportunity to learn while attending to patients in a teaching hospital. ${ }^{30}$ The method adopted in teaching medical students is said to provide opportunity for role playing, teaching of transferable skills, increased learner motivation, increased professional thinking; , and integration of clinical skills, communication skills, problem-solving, decision making and ethical challenges. ${ }^{31}$ It follows that medical clinical education is structured in such

\footnotetext{
30 Yousef Marwan, Muhammad Al-Saddique, Adnan Hassan, Jumanah Karim and Mervat Al-Saleh, 'Are Medical Students Accepted by Patients in Teaching Hospitals?' (2012) Medical Education 1. 31 ibid.
} 
a manner to ensure that all the above skills in addition to study of medicine, are imbibed by the medical student. This should also be the strategy for CLE in a law faculty in Nigeria.

In the initial business plan for the clinic, office hours for the clinic should be determined. It will need to be decided whether the clinic should operate when school is not in session. If the clinic is offering pro bono services as well as representing real clients in court, it may be necessary to have the clinic operational during school breaks but with volunteer counsel.

It may help to define a practice theme for the clinic as this would help for cohesion and serve as a driver for success. A theme such as access to justice or human rights could be a good starting point. The benefits of such strategy is that it will aid the building of internal expertise, add coherence to the programme and have a greater impact. $^{32}$

Furthermore, in the plan for the clinic, the mode of attracting clients should be considered. It is also possible that since the services are free, the clinic may be over subscribed by clients. It follows that there should be a standard in place to serve as a guide for sourcing pro bono work and ways to reject those whose cases the clinic may unfortunately not handle due to capacity. Some of the ways to source for clients include, working with community leaders and organisations to inform them about the

\footnotetext{
32 The Law Society, 'Developing a Pro Bono Programme' (2015) available at < file:///Users/admin/Downloads/developing-pro-bono-guide-and-toolkit-october-2015.pdf $>$ accessed 24 September 2018.
} 
clinic, creating partnerships with NGOs, client self-referrals and encouraging students to identify a need personal to them. ${ }^{33}$

\section{ENGAGING STUDENT ADVISERS/PARTICIPANTS}

Students generally lose steam and focus in activities that are not directly graded to impact on their final results. As such, they may not continue to focus on their roles in the clinic with the same initial passion that they had when they were introduced to the clinic. This writer observed this trend while serving as a supervisor in a law clinic. Students gave several reasons why they did not turn up when they should for clinic activities. These ranged from having other school assignments, lectures or tests scheduled for the same period as the clinic activity. For some, this writer observed that after a while the students lost interest because they were either afraid of making mistakes or they simply did not want to appear lazy before their colleagues in cases where they did not know how to approach their tasks. It is recommended that the law faculty makes a decision on what time they operate the clinic to ensure that this does not clash with other faculty activities.

Furthermore, a reward system should be encouraged to engage the students. The supervisors and other staff of the law faculty should provide support to students who may require additional time to catch up. A friendly atmosphere for learning should

${ }^{33}$ Ibid. 
be encouraged to make the clinic conducive for all. In addition, values such as mutual respect by the students for one another must remain sacrosanct.

\section{CONCLUSION}

Clinical legal education is now regarded as an important aspect of the law school curriculum in many countries of the world including Nigeria. It is imperative that where law clinics are established, they should function as a means for the provision of free legal services and for learning. A law clinic is also an opportunity for the faculty and the University to give back to the immediate community. This article argues in support for the establishment of law clinics as a way of promoting clinical legal education in the law faculties in Nigeria. The Law clinic in the University of Maiduguri was briefly examined. The model that University has adopted is for students in Year four and five to take CLE as an elective course in the first and second semesters in two academic sessions. While this is encouraging for a start, this writer is of the opinion that CLE should be compulsory for all law students especially in the fifth year of the LLB programme. A primary focus of the discussion is that law clinics in the law faculties across the country should not be set up merely for only providing opportunities for simulation and the creation of public awareness for example, organising public activities to discuss human rights with members of the community. Rather, the article strongly recommends for law clinics to be set up in the same fashion as medical clinics at teaching hospitals are established. 
The goal is to provide students with real-live lawyer-client scenarios and opportunities. The advantage of using this model is that the student profits from the experience of providing solutions to problems of real clients and the fulfilment that can derive from it. To get the participation of students and to ensure commitment, the law clinic module should be introduced as a mandatory module to be studied before graduation even though it may not count towards final degree classification; attendance and participation should determine if a student has passed the module. Finally, it is recommended that students who desire to apply to a law school should consider the law clinic and the immense benefits that can be derived from that decision.

\section{References}

Adelakun-Odewale, O. S. (2017) 'Role of Clinical Legal Education in Social Justice in Nigeria’ Asian Journal of Legal Education, 5(1), 88-98. doi:10.1177/2322005817730148

Alvarez, G. (2018) ‘Law Firm Target Audience: Reaching Your Ideal Client' Retrieved from https://good2bsocial.com/law-firm-target-audience/>

Du Plessis, M. A. (2015) 'Clinical Legal Education: Determining the Mission and Focus of a University Law Clinic and Required Outcomes, Skills \& Values' De Jure, 48(2), 312-327. doi:10.17159/2225-7160/2015/v48n2a4

Faculty of Law, University of Maiduguri (2018), 'Faculty of Law' Retrieved from http://www.unimaid.edu.ng/faculty/law.html

Fahy, R., \& Eechoud, M. V. (2015). Establishing a Start-up Law Clinic in Law School: A Practical Guide. ICT Incubators Network. 
Find Law, (2018) 'How to Start a Law Firm: Office Furniture and Supplies' Retrieved from https://practice.findlaw.com/how-to-start-a-law-firm/how-to-start-a-law-firm-officefurniture-and-supplies.html

Grimes, R. (1996) 'The Theory and Practice of Clinical Legal Education' In J. Webb \& C. Maughan (Eds.), Teaching Lawyers' Skills. Butterworths Law.

Kerrigan, K., \& Murray, V. (2011) A Student Guide to Clinical Legal Education and Pro Bono. Houndmills, Basingstoke: Palgrave Macmillan.

Kift, S. (2003) 'A Tale of Two Sectors: Dynamic Curriculum Change for a Dynamically Changing Profession' Paper presented at Developing the Law Curriculum to Meet the Needs of the 21st Century Legal Practitioner Conference, Melbourne, Australia. Retrieved from https://core.ac.uk/download/pdf/10877994.pdf

The Law Society. (2015). 'Developing a Pro Bono Programme' Retrieved from file:///Users/admin/Downloads/developing-pro-bono-guide-and-toolkit-october-2015.pdf

Marwan, Y., Al-Saddique, M., Hassan, A., Karim, J., \& Al-Saleh, M. (2012) Are Medical Students accepted by Patients in Teaching Hospitals? Medical Education Online, 17(1), 17172. doi:10.3402/meo.v17i0.17172

Meghdadi, M. M., \& Nasab, A. E. (2011) ‘The Role of Legal Clinics of Law Schools in Human Rights Education: Mofid University Legal Clinic Experience' Procedia - Social and Behavioral Sciences, 15, 3014-3017. doi:10.1016/j.sbspro.2011.04.234

National Human Rights Commission (2017) Annual Report 2016 Retrieved from https://www.nigeriarights.gov.ng/downloads/NHRC\%202016\%20ANNUAL\%20REPORT.p $\underline{\mathrm{df}}>$

Network of University Legal Aid Institutions (2018) 'The Development of Clinical Legal Education' Retrieved from http://www.nulai.org/index.php/blog/83-cle

Oke-Samuel, O. (2008) 'Clinical Legal Education in Nigeria' Griffith Law Review, 17(1), 139150. doi:10.1080/10383441.2008.10854605

Wizner, S. (2002) ' The Law School Clinic: Legal Education in the Interest of Justice. Fordham Law Review, 70, 1929. 